Красівський Денис Орестович

кандидат наук з державного управління, провідний науковий співробітник проблемної науково-дослідної лабораторії соціальних досліджень ринку праці Інституту підготовки кадрів державної служби зайнятості України ORCID 0000-0002-2661-8592 krasivskiy.denis@gmail.com

\title{
МІЖКУЛЬТУРНА КОМУНІКАЦІЯ В КОНТЕКСТІ ГЛОБАЛІЗАЦІЇ ТА ÏÏ ВПЛИВ НА САМОВИЗНАЧЕННЯ УКРАЇНЦІВ ЗАКАРПАТТЯ
}

Мета статті полягає в аналізі сучасних наукових тенденцій в сфрері міжкультурної комунікації в контексті глобалізації та її вплив на самовизначення українців Закарпаття. Методологія дослідження полягає у застосуванні компаративного, історико-логічного, аналізу та синтезу методів, які дозволяють розкрити та піддати вивченню певних тенденцій міжкультурної комунікації в Закарпатті та її впливу на ідентифікацію громадян з метою знайти динамічний погляд на розвиток міжкультурної комунікації в поліетнічному регіоні. Наукова новизна роботи полягає у здійсненні теоретичного аналізу сучасних тенденцій міжкультурної комунікації на Закарпатті з врахуванням загальносвітового тренду до глобалізації. Аналіз сучасних тенденцій дає підстави краще розуміти міжкультурні процеси в поліетнічному суспільстві, його перспективи та загрози. Висновки. Осмислення розвитку парадигмальних систем, що засновані на міжкультурній комунікації регіону дає нову точку відліку для реформаторської діяльності, в напрямку зближення регіону з загальнодержавними інтересами. Це слід враховувати при формуванні комунікативної стратегії держави в умовах міжнародної інтеграції та глобалізації, що включає здатність до міжкультурної взаємодії в межах регіону в якому спостерігаємо світові тренди міжкультурної комунікації, такі як глокалізація, та детериторізація при явному напрямку у висококонтекстне суспільство.

Ключові слова: міжкультурна комунікація, Закарпаття, глокалізація, глобалізація, детериторізація, контекстність культур.

Красивский Орест Якубович, доктор исторических наук, профрессор, Институт Европейской Культуры Университета им. Адама Мицкевича; Красивский Денис Орестович, кандидат наук по государственному управлению, ведущий научный сотрудник проблемной научно-исследовательской лаборатории социальных исследований рынка труда Института подготовки кадров государственной службы занятости Украины

Межкультурная коммуникация в контексте глобализации и ее влияние на самоопределение украинцев Закарпатья

Цель статьи заключается в анализе современных научных тенденций в сфере межкультурной коммуникации в контексте глобализации и ее влияние на самоопределение украинского Закарпатья. Методология исследования заключается в применении сравнительного, историко-логического, анализа и синтеза методов, которые позволяют раскрыть и подвергнуть анализу определенные тенденции межкультурной коммуникации в Закарпатье и ее влияния на идентификацию граждан с целью найти динамичный взгляд на развитие межкультурной коммуникации в полиетничном регионе. Научная новизна работы заключается в осуществлении теоретического анализа современных тенденций межкультурной коммуникации на Закарпатье с учетом общемирового тренда к глобализации. Анализ современных тенденций дает основания лучше понимать межкультурные процессы в полиэтническом обществе, его перспективы и угрозы. Выводы. Осмысление развития парадигмальных систем, основанных на межкультурной коммуникации региона дает новую точку отсчета для реформаторской деятельности, в направлении сближения региона с общегосударственными интересами. Это следует учитывать при формировании коммуникативной стратегии государства в условиях международной интеграции и глобализации, включая способность к межкультурному взаимодействию в пределах региона в котором наблюдаем мировые тренды межкультурной коммуникации, такие как глокализация, и детериторизация при явном уклоне в висококонтекстное общество.

Ключевые слова: Межкультурная коммуникация, Закарпатье, глокализация, глобализация, детериторизация, контекстность культур.

Krasivsky Orest, Doctor of Habilitation, Professor, Ordinary, Adam Mickiewicz Institute of European Culture Krasivsky Denys, PhD (Public Administration), Senior Researcher, Problem Research Laboratory of Social Research of the Labor Market, Ukrainian, State Employment Service Training Institute (USESTI)

Intercultural communication in the context of globalization and its impact on the self-definition of Ukrainians of the Transcarpathia

(С) Красівський О. Я., 2020

(С) Красівський Д. О., 2020 
The purpose of the article is to analyze current scientific trends in the field of intercultural communication in the context of globalization and its impact on the self-determination of Transcarpathian Ukrainians. The methodology of the study is to apply a comparative, historical, logical, analysis and synthesis of methods that allow to reveal and analyze certain trends of intercultural communication in Transcarpathia and its impact on the identification of citizens in order to find a dynamic view of the development of intercultural communication in the multi-ethnic region. The scientific novelty of the work is to carry out a theoretical analysis of current trends in intercultural communication in Transcarpathia, taking into account the global trend towards globalization. An analysis of current trends provides a basis for a better understanding of intercultural processes in a multi-ethnic society, its perspectives, and threats. Conclusions. Understanding the development of paradigmatic systems based on the intercultural communication of the region gives a new point of reference for reform activities, in the direction of bringing the region closer to national interests. This should be taken into account when shaping the state's communication strategy in the context of international integration and globalization, which includes the ability to intercultural interaction within the region where we see global trends in intercultural communication, such as globalization, and deteritization with a clear bias in highly contextual society. Intercultural communication as a whole is still characterized by low-context communication (as opposed to communication within the native culture): communicators intuitively understand that their interlocutors - foreigners - do not have a good knowledge of the local cultural context.

Key words: intercultural communication, Transcarpathia, glocalization, globalization, deterritorisation, the context of cultures.

Постановка проблеми. В сучасному науковому середовищі все більше розповсюджується думка про те, що кожна держава та суспільство відчувають етнічні виклики та загрози у зв'язку з процесами глобалізації та міграції. Прояви таких викликів та загроз спостерігаються в збільшенні етнічної конкуренції, в спробах етнічного домінування, у проявах міжетнічної боротьби, винекненні ультраправого націоналізму тощо. Такого роду процеси відбуваються не тільки в глобальному масштабі, хоча саме глобальний масштаб є найбільш помітним для світового суспільства. 3 різноманітних проявів складаються стійкі етнополітичні тенденції, які здійснюються в межах національних держав, окремих регіонів, та локальних поселень. Подібні виклики та загрози перетворюються у перманентну повсякденну ситуацію, яка вимагає уміння напрацьовувати нові засоби управління в поліетнічних регіонах. В межах України саме Закарпатська область є таким поліетнічним регіоном з великою кількістю етнічних груп. Дослідження їх міжкультурної комунікації дозволить врахувати сучасні тренди, загрози та перспективи розвитку Закарпаття в період глобалізації.

Аналіз останніх досліджень та публікацій: Теорії міжкультурної комунікації досліджували провідні зарубіжні дослідники як Д.Крістал, Л.Демін, М. Бодзяни, Р.Робертсон, Р. Вьюєр, М.Вебер, Е. Гідденс. А. Моль, Д. Фішман. Поняття національної ідентичності досліджувалось Е. Кедурі, І.Г. Фіхте М. Биллигом, М. Макаровим. Проблемам поліетнічності регіонів України присвячені праці Л.Белея, Ю.Бідзіля, О. Мальця, О. Олійника та ін. Однак сучасні тенденції поліетнічних регіонів вказують на недостатнє вивчення даної проблематики, та потребують більш детальних досліджень.

Мета статті: визначення сучасних наукових тенденцій міжкультурної комунікації в контексті глобалізації та її вплив на самовизначення українців Закарпаття.

Виклад основного матеріалу. У сучасному світі основними формами існування людського суспільства $€$ нації і держави, які об'єднані в «міжнародний світ націй»[13]. Е. Гідденс визначав національну державу як «сукупність інституційних форм управління, що підтримують адміністративну монополію певної території (межі), панування яких санкціоновано законом і прямим контролем над засобами внутрішнього і зовнішнього примусу і насильства; а всі держави існують в комплексі інших національних держав»[13]. Можна говорити про те, що процес визначення національної ідентичності $€$ відправною точкою для виникнення такого явища, як націоналізм. Національна ідентичність передбачає певну волю до згуртованості, але відсутність національної мови неможливо для визначення національної ідентичності. Одним з учених, які досліджували поняття національної ідентичності був Е. Кедурі, на думку якого, мова представлялась як невід'ємний елемент дискурсу та ідентичності нації[15]. І.Г. Фіхте вважав, що люди, які говорять однією мовою, за своєю природою схильні до взаєморозуміння тому, що являють собою єдине ціле [9, 53].

У контексті глобалізації практично усіх сторін суспільного життя, зв'язок між мовою та соціальною структурою суспільства вивчається з двох протилежних підходів. Перший, це конструктивістський підхід, який базується на теоріях М.Вебера, Е.Дюркгейма, К.Маркса, вказує на верховенство соціальних, політичних та економічних фракторів які $є$ присутні в житті націй та етнічних груп. Основним тут виступає обумовленість етнічності культурною ідентифікацією. Культурна самобутність при цьому не впливає на соціальну ідентифікацію, не приймаючи до уваги уніфікацію всіх сфер суспільства в глобальному світі. Інший підхід - примордіалістський, базується на першочерговості локальних соціокультурних характеристик. Причому важливість таких характеристик виростає як реакція на раціональність та універсалізацію [21, 117].

Вищеозначені протилежності між двома поглядами лежать на поверхні, однак, при ретельному аналізі ми можемо побачити протиріччя між єдиним простором мега-культур та простором етнічного та соціокультурного різноманіття. На думку конструктивістів у світі функціонує набагато більше культур та мов ніж вони вважають необхідними та доцільними. Прімордіалісти наводять як приклад минулі культурні моделі, закликають дотримуватись різноманітності культур та мов. На їх думку це лежить в 
площині моральної відповідальності за підтримку соціокультурних течій та мовних різноманітностей. Так, на думку соціолінгвіста Д.Фішмана, існує певний конфлікт викликаний складними проблемами глобального світу націй та мов [21]. Так, на початку свого створення Парламент Європейського Союзу проголосив принцип рівноправності всіх мов, що використовувались в країнах-членах ЄС і перші дванадцять держав використовували в своїй діяльності дев'ять мов. Логічне і правильне рішення на той час, тепер діє вже не так ефективно, оскільки наддержавне утворення розрослось до двадцяти восьми країн-членів.

Таким чином, державна політика в сфері міжкультурної комунікації, як явище і як тенденція в умовах глобалізації може призводити до різних наслідків і результатів міжкультурної комунікації; ефективне планування і збалансована політика окремих держав і міждержавних об'єднань могли б сприяти подоланню міжкультурних бар'єрів як в Україні, так і в окремо взятому Закарпатті.

Унікальне географічне положення, історико-етнографічні процеси, численні і різноманітні духовно-релігійні, а також національні громади зумовили специфічність історико-культурного та економічного розвитку Закарпаття. За свою історію Карпатський край належав Угорському королівству, де частина Закарпаття входила до складу Галицько-Волинського князівства, після - центральні і східні райони належали Османській імперії. Пізніше було встановлено панування Австро-Угорської імперії Габсбургів, яке тривало аж до Першої світової війни. У період між двома світовими війнами землі Закарпаття перебували під владою Чехословаччини. Напередодні німецького вторгнення, у березні 1939 року в краї була проголошена незалежність в якості Карпатської України, і, знову опинився під владою Угорщини, де й перебував аж до кінця Другої світової війни і входження до складу УРСР. Наступний виток історичного розвитку Закарпаття припав вже на 1991 рік, в результаті виходу України зі складу СРСР. Як видно тільки за останні 100 років територіально Закарпаття перебувало у складі шести країн. Зараз же Закарпаття межує з Румунією, Угорщиною Словаччиною та Польщею.

Зрозуміло, таке історико-географічне не могло не накласти свій етнографічний відбиток на національний, релігійний і мовний склад краю. Згідно з останнім переписом, який був здійснений в 2001 році в Закарпатті проживало понад 85 етнічних груп, основні серед яких: українці, які власне діляться на 4 специфічні етнографічні групи (бойки, лемки, гуцули, долиняни); угорці; румуни; росіяни; цигани; словаки; німці; білоруси; євреї; поляки [20].

Таким чином, історико-етнографічна специфіка регіону дала можливість населенню стати учасниками активної міжкультурної комунікації набагато раніше, ніж населенню інших регіонів України, населених більш однорідним етносом. Також, саме необхідність міжкультурних комунікацій привела, на нашу думку, до формування у населення Закарпаття такого явища як мультилінгвізм (багатомовність).

Власне кажучи, багатомовність в Карпатському краї відіграє істотну роль, оскільки навіть українська мова тут представлена специфічною різноманітністю підкарпаторусинських мов. Серед них різноманітна кількість некодіфрікованих говірок в південно-західній частині краю, представлених тими закарпатцями які називають себе «русини» [17, 177-18]. Окрім усього іншого, в краї спілкуються ще на 17 мовах, діалектах і говірках, найпоширенішими серед яких $€$ лемківський, середньозакарпатский i гуцульський діалекти. Міжкультурна комунікація населення Карпатського краю є в пинципі особливою фрормою спілкування при якій способи реалізації різноманітних ситуацій не ідентичні, тобто мають істотні відмінності в їх реалізації та інтерпретації. Таким чином, поліетнічність, полікультурність і поліментальність населення Карпатського краю створили свій унікальний полікультурний простір.

Явище такого роду як мультилінгвізм притаманне багатьом регіонам як України, так і регіонах інших країн, які не є моноетнічними, хоча сучасні тренди до міграції не залишають подібні країни не зацікавленими. Взагалі питання багатонаціональності, поліетнічності зараз стоїть на порядку денному багатьох держав, і з розмиванням національних кордонів стає все гострішим. Звичайно, також чималу роль тут відіграє цифрова комунікація, особливо враховуючи розвиток сучасних систем спілкування, а також існуючі міграційні процеси, як внутрішні, так і зовнішні.

Характерною рисою подібних міграційних процесів можна назвати теорію трансформації відносин між місцем проживання людини і її культурними, соціальними традиціями, досвідом та ідентичністю. Вперше теорія «детериторізації» була оппроаналізована в дослідженнях Е. Гідденса та Д. Харнея, які базуючись на ідеї канадського філософра М. Макклюена висловили ідею про те, що «детериторізація» передбачає лише трансформацію локальності в світовому просторі, залишаючи існуючі культурні зв'язки та ідентифікацію. У цьому ж контексті ми можемо розглядати внутрішню міграцію сільських жителів у великі міста, коли фрізично відірвані від своїх історичних коренів, мігранти завдяки засобам комунікації не втрачали зв'язку з етнічною батьківщиною. Більше того, перебуваючи далеко мігранти створювали свої культурні центри на місцях. Прикладом таких культурних центрів зараз $є$ земляцтва. По всій території України і за кордоном діють регіональні центри земляцтва українців Закарпаття, русинів, гуцулів. Таким чином, ми можемо розглядати процес «детериторізації» перш за все, як процес культурної комунікації, де локальна культура впливає на розвиток глобальної, привносячи нові елементи, або даючи поштовх до розвитку традиційних. Яскравим прикладом тут буде виступати перемога української співачки на Євробаченні-2004, де в своєму виступі вона використовувала стилізовані під гуцульську субкультуру наспіви і антураж. 
Дещо іншим процесом в системі міжкультурної комунікації Карпатського регіону виступає ідея глокалізації[5, 349], поняття про яку вперше ввів американо-британський вчений Р. Робертсон і визначив її як «регіональну реакцію на світову глобалізацію», яка лежить в площині співвідношення глобального та локального»[6, 191-208]. Для глокалізації характерною рисою виступає, по-перше, те, що вона показує вростання елементів глобальної культури в місцеву. По-друге, глокалізація сприяє функціонуванню регіональних культур в умовах глобалізації. Причому функціонування відбувається на тлі зростаючих тенденцій до сепаратизму раніше усталених культурних зв'язків і звичаїв. I по-третє, глокалізація характеризується впровадженням локальної культури в систему загальних, більш глобальних взаємозв'язків [19].

Для Закарпаття ідея глокалізації викликає пильний інтерес, оскільки зі 130 національностей України, 85 проживають саме в Закарпатті. Відповідно така полікультурність може стати важливою запорукою як успішності соціальних, політичних і економічних перетворень, так і виступити фактором їх провалу. Вплив міжкультурної комунікації на національну ідентичність тут стає наріжним каменем в пошуку загальних соціокультурних смислів, які об'єднують наративів. Особливо важливим це є 3 оглядкою на істотний вплив історичного минулого, сучасних геополітичних чинників, громадянського суспільства, що тільки формується, регіональної поляризації суспільства. Вищезазначені тенденції можуть проявиться також через посилення ізольованості міжрегіональної соціокультурної комунікації.

Тому важливим тут бачиться сучасний діалог культур, який відбувається внаслідок взаємодії представників різних етносів Закарпаття. При цьому варто відзначити, що внаслідок такої взаємодії соціокультурне спадщина може, як і збагатиться так випробувати якісь втрати, в зв'язку з можливим процесом акультурації, під час якого одна культура проектує на себе особливості інший [5].

Варто відзначити, що поліетнічність Закарпаття, яке межує з чотирма європейськими державами, сприяла організації програм (Закарпатська державна телерадіокомпанія) угорською, румунською, словацькою, німецькою та ромською мовами $[11,12]$. Природньо, що комунікативна взаємодія в домашньому побуті і на роботі розрізняються за ступенем впливу особистісних аспектів і занурення в побутову культуру. До поняття внутрішнього контексту відносяться: широкий спектр фонових знань, культурна і національна ідентичність, ціннісні установки і всі індивідуальні особливості мовної особистості. Сюди ж можна віднести і варіації психологічного контексту комунікації - доброзичливий, серйозний або гумористичний настрій комунікаторів [7, 22 - 23].

Хронологічний період або тимчасовий контекст моменту вчинення комунікації теж впливає на її результат. У різні часові проміжки міжнародний авторитет держав і міждержавні відносини знаходяться на різних рівнях, що не могло не позначитися на самоідентифікації учасників міжкультурної комунікації, на відчутті їх збитковості або величі, ставлення до співрозмовника і інших проявах динаміки міжкультурної комунікації. У підсумку, як ми писали вище, Закарпаття в різний час належало різним державам, відповідно до чого змінювався домінуюча мова учасників міжкультурної комунікації.

Необхідно відзначити, що з хронологічних позицій міжкультурна комунікація буває одночасною або різночасною. При цьому лінійність спілкування підтверджує відносний характер одночасності комунікації. Одночасним вважається особисте спілкування, телефонна розмова і онлайн спілкування в інтернеті. Невеликий розрив у часі є при відправці та отриманні електронної пошти і трохи більший за відправку та отримання листа традиційним способом - звичайною поштою. Роки століття пов'язує комунікація через твори літератури і мистецтва. Унаслідок асинхронності в розвитку різних культур простежується їх випередження або відставання за різними параметрами, що призводить до порушень когерентності процесів міжкультурної комунікації. Подібне явище ми можемо спостерігати в «плавильному котлі» національностей Закарпатської області, де проживають і взаємодіють численні громади які проте мають різні стартові умови. Як вказував французький філософ і культуролог А.Моль «сучасна людина виробляє свою культуру не шляхом цілеспрямованої діяльності щодо подальшого розвитку основ знань, придбаних ним за роки освіти, а під впливом безперервного потоку окремих елементів культури, які поступово накопичуються в загальному процесі культурної діяльності. Таке накопичення не $є$ результатом цілеспрямованих зусиль з придбання систематичних знань - це не відповідає самій суті життя в наш технічний вік; воно відбувається внаслідок постійного припливу із зовнішнього середовища найрізноманітнішої інформації» [18, 119]. Таким чином, виходячи з цієї тези, можемо спостерігати постійний вплив на жителів Закарпаття найрізноманітнішої зовнішньої інфрормації, в основі якої лежить новий тип світогляду і міжкультурної комунікації в регіоні.

Елементи зовнішньої ідентичності контекстів можуть призводити комунікаторів до помилкових висновків і помилок. Наприклад, культура професійного спілкування не тільки в різних країнах, але і в різних регіонах країни різниться за рівнем використовуваної стратегії, дистанційованості між начальником і підлеглим, формальності або неформальності. Так, культура спілкування русинів і гуцулів Закарпаття відрізняється від культури спілкування закарпатських німців або угорців.

Американським дослідником Е. Холом, було розроблено загальноприйняте нині розмежування низькоконтекстних і висококонтекстних культур. Висококонтекстною вважається культура, в якій базисна інформаційна частина проявляється на рівні зовнішнього або внутрішнього контекстів. Низькоконтекстні культури характеризуються кодуванням в повідомленні здебільшого інформації, що підлягає обміну між співрозмовниками, на експліцитному рівні [4]. 
Ознаками таких низькоконтекстних культур можна вважати динамічний, високотехнологічний рівень прогресу. Висококонтекстні культури прийнято співвідносити з традиційним укладом, їм притаманні стійкість, несхильність до емоційності і змін. Види інформаційного обміну висококонтекстною культурою відрізняються ефективністю і економічністю завдяки ефективному використанню контексту. Американська культура, на думку багатьох дослідників, відноситься до категорії низькоконтекстних. У той час українська культура $є$ висококонтекстною через сформовану думку про те, що одну з головних ролей комунікаційного контексту відіграє колективізм. Але не можна не відзначити, що в історичному плані Україна в цілому, і Закарпаття, зокрема, постійно перебувала під сильним впливом як Заходу, так і Сходу, що дозволяє зробити висновок про її проміжному положенні між західним низькоконтекстним світом і східними висококонтекстними культурами.

Небезпека при взаємодії культур складається в можливості недооцінки важливості комунікаційного контексту, або навпаки, в переоцінці ролі даного моменту. Відомо, що поведінка американців часто розцінюється представником висококонтекстної культури як нетактовна і неввічлива. Це відбувається тому, що середньостатистичний американець не враховує належним чином ролі контекстуальної інформації при спілкуванні з партнером по комунікації [5]. У свою чергу, носії висококонтекстних культур часто звинувачуються в недостатній ясності та чіткості вираженості думки, скритності і небажанні говорити правду.

Міжкультурній комунікації в цілому притаманне все ж низькоконтекстне спілкування (на відміну від комунікації в рамках рідної культури): комунікатори інтуїтивно розуміють, що їх співрозмовники іноземці - не цілком добре володіють інформацією місцевого культурного контексту. У подібних ситуаціях необхідно дотримуватися почуття міри і рівноваги для того, щоб пояснення контексту не перетворилося в нав'язливе роз'яснення, образливе для комунікатора, а реально служило б цілям спілкування $[9,53]$.

Ідеальним варіантом, на наш погляд, буде установка розумного рівноваги між новою і вже відомою інформацією, яка будується на об'єктивному сприйнятті чужої і рідної культури. Що до параметрів змісту інформації, то важливим тут виступає вміння правильно вибрати прийнятну для всіх учасників комунікації тему спілкування, яка називається комунікативною компетентністю. Перевірені безпечні для спілкування з малознайомими співрозмовниками теми: погода, клопоти з дітьми, домашні тварини і іноді рід занять. Напруженими темами вважаються расові, сексуальні проблеми, релігія і політика, а також етнічні [2, 117].

У 2017 році вже виникав конфрлікт на етнічному ґрунті між Угорщиною та Україною який завдав істотної шкоди Україні не тільки у внутрішній політиці, а й у зовнішній. Так, уряд Угорщини через прийняття Закону України «Про забезпечення функціонування української мови як державної», а саме через статті, які стосуються мов національних меншин [14], мав і має намір блокувати всі спроби Євросоюзу продовжувати процес інтеграції України. Більш того, МЗС Угорщини заявив, що буде домагатися розірвання вже досягнутих домовленостей, якими так пишається Київ - зокрема, режиму безвізового в'їзду в шенгенську зону. Зі свого боку МЗС України зробило заяву про те, що Угорщина має право піднімати будь-яке питання в рамках ЄС. Але рішення щодо України не можуть прийматися без України, яка платить надзвичайно високу ціну за своє місце в Європі. Зокрема, якщо звернутися до внутрішньополітичної ситуації в самій Угорщині, то через ескалації конфлікту між країнами ряд угорських політичних сил почав розігрувати карту сепаратизму в Закарпатській Україні. Так, наприклад, угорська партія «Йоббік» мала намір провести акцію «Самовизначення для Закарпаття». У березні 2014 року партія вже проводила аналогічні акції в підтримку Криму і Донбасу.

Висновки. Осмислення розвитку парадигмальних систем, що засновані на міжкультурній комунікації регіону дає нову точку відліку для реформаторської діяльності, в напрямку зближення регіону з загальнодержавними інтересами. Це слід враховувати при формуванні комунікативної стратегії держави в умовах міжнародної інтеграції та глобалізації, що включає здатність до міжкультурної взаємодії в межах регіону в якому спостерігаються світові тренди міжкультурної комунікації, такі як глокалізація, та детериторизація при явному ухилі в напрямку висококонтекстного суспільства.

\section{תimepamypa}

1. Appadurai Arjun. Disjuncture and Difference in the Global Cultural Economy. Theory, Culture \& Society, 1990, vol. 7, p. 295-310. https://doi.org/10.1177/026327690007002017

2. Crystal D. The Cambridge Encyclopedia of Language. Cambridge University Press, 1987. p. 117

3. Damen L. Culture Learning: The Fifth Dimension in the Language Classroom. U. S. A. Addison-Wesley Publishing Company, 1987. p. $77-79$.

4. Hall E. T. Understanding Cultural Differences: Germans, French and Americans. Intereultural Press, 1990, p. 224

5. Marek Bodziany, "Komunikacja międzykulturowa w wielonarodowych jednostkach wojskowych". Wydawnictwo Uczelniane Wyższej Szkoły Oficerskiej Wojsk Lądowych imienia generała Tadeusza Kościuszki, Warsawa, Poland, 2012, 349 p

6. Robertson R., White K., Globalization or glocalization? Globalisation. Critical concept in sociology. Vol. III, London. 2003, p. 191-208 
7. Weaver II R. L. Understanding Interpersonal Communication. 7-th ed. HarperCollins College Publishers, 199 , p. $22-23$

8. Белей Л. «Русинський сепаратизм»: націєтворення in vitro. Київ: Темпора, 2017, 392 с.

9. Биллиг М. Нации и языки, Москва: Логос. 2005, №4 (49), с. 53.

10. Бідзіля, Ю. М. Інформаційна безпека поліетнічного регіону: пошук нової медіасистеми (на прикладі Закарпаття). Наукові записки Інституту журналістики. 2014, т. 56, с. 195-203

11. Бідзіля, Ю. М. Угорськомовна преса на Закарпатті. Наукові записки Інституту журналістики. 2013, т.52, с. $211-219$

12. Бідзіля, Ю. Масмедіа Закарпаття як чинник міжкультурної комунікації. Науковий вісник Ужгородського університету. Серія: Філологія. Соціальні комунікації. 2013, Вип. 1, с. 283-293

13. Гидденс, Э. Социология. Москва: Эдиториал УРСС, 1999, 703 с.

14. Про забезпечення функціонування української мови як державної: Закон України, від 25.04.2019 № 2704-VIII. Відомості Верховної Ради, 2019, № 21, ст.81

15. Кедури Є, Национализм. Санкт-Петербург: Алетейя, 2010, 136 с.

16. Макаров М.Л. Интерпретативный анализ дискурса в малой группе. Тверь: Твер. гос. ун-т, 1998, с.114 $-116$.

17. Малець О.О. Етнокультурні процеси на Закарпатті в період утвердження тоталітарного режиму в перші роки визволення (жовтень 1944 - початок 50-х рр. XX ст.) Вісник Закарпатського художнього інституту. 2014, Вип. 5, с. 177-181.

18. Моль А. Социодинамика культуры. Москва: Прогресс, 2005, 406 с.

19. Олійник О. М. Концептуалізація глокалізації: методологічні аспекти. Гуманітарний вісник 3ДІА. 2009, URL: http://www.zgia.zp.ua/gazeta/VISNIK_38_4.pdf.

20. Офріційне інтернет представництво Державної служби статистики України. режим доступу: http://www.ukrstat.gov.ua/

21. Фишман Д. Сегодняшние споры между примордиалистами и конструктивистами: связь между языком и этничностью с точки зрения ученых и повседневной жизни. Москва, Логос. 2003, №4(49), с. 117.

\section{References}

1. Appadurai Arjun (1990). "Disjuncture and Difference in the Global Cultural Economy", Theory, Culture \& Society, ed. 7. [in English].

2. Crystal D. (1987). "The Cambridge Encyclopedia of Language." New York; Port Chester; Melbourne; Sydney; Cambridge: Cambridge University Press, 117 [in English].

3. Damen L. (1987). "Culture Learning: The Fifth Dimension in the Language Classroom." U. S. A.: AddisonWesley Publishing Company, 77 - 79. [in English].

4. Hall E. T. (1990). "Understanding Cultural Differences: Germans, French, and Americans.", Intereultural Press, [in English].

5. Marek Bodziany (2012). "Komunikacja międzykulturowa w wielonarodowych jednostkach wojskowych". Wydawnictwo Uczelniane Wyższej Szkoły Oficerskiej Wojsk Lądowych imienia generała Tadeusza Kościuszki, Warsawa, Poland, 349 [in Polish].

6. Robertson R. (2003). "Globalization or glocalization?" [Globalisation. Critical concept in sociology.] Vol. III, London. 191-208 [in English].

7. Weaver II R. L. (1996). Understanding Interpersonal Communication. 7- th edition. HarperCollins College Publishers, $22-23$ [in English].

8. Beley L. (2017). Rusyn separatism, [Rusyns'kyy separatyzm], Tempora, Kyiv, Ukraine, 392 [in Ukrainian].

9. Billig M. (2005). Nations and Languages, [Natsii i yazyki] Vol 4 (49), 53. [in Russian].

10. Bidzilya, YU. M. (2014). "Information security of the polyethnic region: the search for a new media system (for example, Transcarpathia)" [Naukovi zapysky Instytutu zhurnalistyky] Is. 56, 195-203 [in Ukrainian].

11. Bidzilya, YU. M. (2013). "Hungarian-language press in Transcarpathia " [Naukovi zapysky Instytutu zhurnalistyky] Is.52, 211-219; [in Ukrainian].

12. Bidzilya, YU. M. (2013). "Masmedia Transcarpathia as a factor in intercultural communication" [Scientific herald of Uzhgorod University. Series: Philology. Social communication], Vol. 1. 283-293 [in Ukrainian].

13. Giddens E, (1999). Sotsiologiya, [Sociology], Editorial URSS, Moscow, Russia [in Russian].

14. Law of Ukraine "On Ensuring the Functioning of the Ukrainian Language as a State from 25.04.2019 № 2704-VIII. (25, April 2019). Vidomosti Verkhovnoyi Rady, Kyiv, Ukraine № 21, p. 81 [In Ukranian].

15. Keduri Ê, (2010). Natsionalizm, [Nationalism], 4th ed., Aletheia, Saint Petersburg, Russia [in Russian].

16. Makarov, ML, (1998). "Interpretative Discourse Analysis in a Small Group" Tver. state un-t, Russia, Tver, 114 - 116. [in Russian].

17. Malets' O (2014). "Ethnocultural processes in Transcarpathia during the establishment of a totalitarian regime in the early years of liberation (October 1944 - early 50's of the twentieth century.)", [Visnyk of the Transcarpathian Artistic Institute] Vol, 5. 177-181. [in Ukrainian].

18. Mol A. (2005). "Sociodynamics of culture", Progress, Russia, Moscow [in Russian].

19. Oliynyk O.M. (2009). "Conceptualization of Globalization: Methodological Aspects", [Humanitarnyy visnyk ZDIA.] Available from: http://www.zgia.zp.ua/gazeta/VISNIK_38_4.pdf. (Date access 02.02.2019) [in Ukrainian].

20. State Service of Statistics of Ukraine, (2001). "Official census of the population of Ukraine 2001", Available from: http://www.ukrstat.gov.ua/ (Date access 02.02.2019) [in Ukrainian].

21. Fishman D. (2003). "Today's disputes between primordialists and constructivists: the connection between language and ethnicity from the point of view of scientists and everyday life", Logos, Vol 4(49) [in Russian]. 